2. Тонков Е.Е Управление конфликтами в органах внутренних дел: Учебное пособие. - Белгород: ОН и РИО, 2001.

3. Матвеев Д.Д. Организационные методы разрешения конфликта интересов в служебной деятельности сотрудников органов внутренних дел // Закон и право. 2008. №4.

4. Матвеев Д.Д. Урегулирование конфликтов интересов начальником городских и районных органов внутренних дел // Совершенствование управления в системе горрайорганов внутренних дел на современном этапе. Материалы межкафедральной научно-практической конференции в Академии управления МВД России. - М., 2006.

5. Авторский коллектив: В.К. Русаков, Л.М. Колодкин, Г.П. Лозовицкая, О.М. Боева, А.С. Горелов, А.Я. Балкаров, Р.А. Умеров, М.В. Дукманов, О.В. Сибилева Теоретические основы и практика работы кадровых подразделений органов внутренних дел Российской Федерации по вопросам прохождения службы. М.: Академия управления МВД России, 2017. - 88 с.

\title{
Чикурова П.С., Березина А.В. \\ Ментальность и проживание в общежитии как один из факторов адаптации иногородних учащихся (на примере студентов УГЛТУг.Екатеринбург)
}

Уральский государственный лесотехнический университет (Россия, Екатеринбург)

doi 10.18411/spc-04-03-2018-31

idsp 000001:spc-04-03-2018-31

Проблема качества образования, освоения студентами профессиональных знаний и навыков напрямую связана с условиями их проживания, реакцией на окружающую среду и ее восприятие. Актуализация данной проблематики раскрывается при обращении к теме адаптации иногородних студентов, не только к условиям мегаполиса, но и к совместной с другими студентами жизни в общежитии. Как быстро адаптируется первокурсник к жизни вне семьи, без постоянных контактов с родными и близкими? Являются ли условия проживания одним из самых важных факторов адаптации студентов в новом городе?

Существующая проблематика отмечается не только в вузах Екатеринбурга, а так же и в других регионах России [2].Нередко встречаемые проблемы привыкания иногородних молодых людейк новой для них жизни студентов вуза связываются с целым наборомсоциальных, экономических и бытовых проблем, а так же и ментальными проблемами жителей периферии.

Основной задачей, стоящих перед первокурсниками, стала социализация в незнакомых для них условиях мегаполиса и системы вузовского образования. Выбор направления адаптации распределялся следующим образом:

1. стараться соответствовать окружению, подстраиваться под окружающих, не конфликтовать;

2. привлечь внимание сокурсников к своей личности;

3. вести всегда и везде собственную линию, помнить о цели поступления.

На первый взгляд, студентыраспределяются только на три группы, согласно выбору направления адаптации к новым условиям, но в реальности картина представляется наиболее сложной и зависит от ментальности обучающегося, его самоидентификации и применимых ценностей к оценке реальности и его окружения.Так, привлечь внимание однокурсников к своей личности можно, как и участием в общеуниверситетских мероприятиях, так и участием в довольно затратных городских «тусовках», растратой денежных средств, так и просто явно маргинальным поведением.

Как показывают исследования только 5 - 7 \% из опрошенных идут этим путем, активно участвуя в мероприятиях вуза, всего от $1-1,5 \%$ выбирают маргинальные направления, и около 4\% (у кого достаточно обеспеченные родители) проводят время в городских тусовках, вынося все молодежные новости на суд студенческой 
аудитории.Показать себя «свободным», «вырвавшимся» из семьи, почувствовать себя «взрослым», демонстрировать полную независимость от чужого мнения.

Часто экономическое положение студента сказывается на его чувстве уверенности в коллективе. Молодые люди хотят показать не только свою успешность в получении знаний, но и соответствовать моде, как в одежде, так и в проведении досуга. «В настоящее время размер государственной академической стипендиидля студентов ВО составляет 2530 руб. 00 коп.»[3]. Суммане для проживания, и если родители не могут помочь в полной мере, то наиболее встречающейся в социально-экономическом плане для приезжих молодых людей проблема нехватки денежных средств становится ведущей. Отсюда поиски дополнительного заработка, пропуски занятий, неуспеваемость.

Большая часть старается бесконфликтно ладить с однокурсниками, осваивать принятые нормы и правила поведения. Здесь опять же вопрос выбора окружения в студенческой среде. Бесконфликтность может привести как к пропуску занятий, к списыванию, не подготовке к сроку даваемых преподавателями заданий. Около 70\% студентов идут именно таким путем, стараясь соответствовать во всем окружению и не выглядеть маргинальным.

Проведение собственной линии поведения также может привести к противоположным результатам. Это возможно, лидерство, и это возможна замкнутость. По нашим наблюдениям студентов с лидерскими позициями насчитывается от 2 до $4 \%$ на разных курсах, а студентов замыкающихся в себе от 5 до $7 \%$, причем с каждым годом количество последних растет.

Успеваемость студента так же зависит и от возможности выполнять задания в спокойной обстановке. Для этого необходимы помещения, должным образом оборудованныемебелью и орг. техникой. Всего в двух из семи общежитий УГЛТУ присутствуют комнаты для занятий. Поэтому наиболее обеспеченные студенты стремятся снять комнаты для отдельного проживания. Но количество таких студентов в вузе доходит до 3\%.Поэтому студенты вынуждены адаптироваться к сложным бытовым условиям проживания.

Молодому человеку необходимо предоставить не менее 12 кв. м индивидуальной площади, комфортный доступ к сан.узлу и кухне. Оборудование, должно быть исправно. В настоящее время, как показали проведенные опросы студентов, большинство общежитий УГЛТУ не соответствует вышеперечисленным условиям. В общежитиях реальная жилая площадь на человека значительно меньше требуемой по нормативам, нередко сан.узлы находится в неисправном состоянии [1], в кухонном помещении недостаточное количество техники для приготовления пищи, а часть этой техники просто неисправна. Но молодежь данную ситуацию вполне готова принять с юмором и решать проблемы совместно. Как показал опрос, среди 100 о степени важности факторов адаптации по 5-бальной шкале (0-неважно,5- очень важно) для 90\% студентов, конечно, важны комфортные условия проживания (исправные души, туалеты, чистота в помещениях), для 20\% опрошенных важным фактором является то, какие люди проживают с ними в одной комнате. Но ключевым моментом для адаптации всех студентов является яркая студенческая жизнь, качество образования, а также социальная поддержка, предоставляемая университетом[см. таблицу].

Таким образом, на успеваемость в вузе достаточно неоднозначно влияют социальная, экономическая и бытовая стороны жизни студентов.

Таблица

Результаты опроса

\begin{tabular}{|c|c|}
\hline Фактор адаптации & Количество студентов \\
\hline Условия проживания & 25 \\
\hline Досуг & 55 \\
\hline
\end{tabular}




\begin{tabular}{|c|c|}
\hline Возможность заниматься уроками & 5 \\
\hline Цель жизни студента & 10 \\
\hline Климат в коллективе & 5 \\
\hline
\end{tabular}

Итак, наиболее важным фактором адаптации для большей части студентов является проблема социализации и проведение досуга. Можно сделать вывод, что эти студенты легко перенесут условия проживания в общежитии и экономические проблемы.

$$
* * *
$$

1. Градобоева Е. Цены на проживание в студенческих общежитиях повысятся в десять раз // Облгазета.Ru URL: https://www.oblgazeta.ru/society/12005/ (Дата доступа: 18.01.2018)

2. Глебов В. В., Кузьмина Я.В.. Эколого-психофизиологические особенности адаптации иногородних студентов первого курса в условиях столичного мегаполиса //Вестник Российского университета дружбы народов. Серия: Экология и безопасность жизнедеятельности, №. 1, 2015, С. 92-98.

3. Размер и условия предоставления стипендий имер социальной поддержки. Официальный сайт УГЛТУ URL: http://www.usfeu.ru/files/razmuslstip2.pdf (дата обращения 20.01.2018) 